\title{
Toxicological Effects of Silver Nanoparticles (Ag-NPs) on Different Physiological Parameters of Tadpoles, Polypedates maculatus
}

\author{
R. Pattanayak ${ }^{1}$, Rakesh Das², A. Das², S. K. Padhi' ${ }^{2}$ S. S. Sahu' ${ }^{1}$, S. Pattnaik' ${ }^{1}$ C. S. K. Mishra ${ }^{1}$, S. S. Mishra ${ }^{2}$, C. S. Mohanty ${ }^{3}$, \\ G. Sinam ${ }^{3}$, H. K. Barman', J. K. Sundaray ${ }^{2}$ and P. Swain ${ }^{2 *}$ \\ ${ }^{1}$ Dept. of Zoology, College of Basic Science and Humanities, Orissa University of Agriculture and Technology, Bhubaneswar, \\ Odisha (751 003), India \\ ${ }^{2}$ ICAR-Central Institute of Freshwater Aquaculture, Kausalyaganga, Bhubaneswar, Odisha (751 002), India \\ ${ }^{3}$ CSIR-National Botanical Research Institute, Rana Pratap Marg, Lucknow, Uttar Pradesh (226 001), India
}

\author{
Corresponding Author \\ P. Swain \\ e-mail: pswainy2k@yahoo.co.in
}

\author{
Article History \\ Article ID: AR1912 \\ Received in 06 ${ }^{\text {th }}$ October, 2018 \\ Received in revised form $31^{\text {st }}$ October, 2018 \\ Accepted in final form 31 $31^{\text {st }}$ October, 2018
}

\begin{abstract}
The effects of silver nanoparticles (Ag-NPs) on the growth, metamorphosis, innate immune parameters and enzyme profiles of tadpole, Polypedates maculatus were studied. Chronic exposure to Ag-NPs for 60 days at $1 \mathrm{mg} \mathrm{l}^{-1}$ and $5 \mathrm{mg} \mathrm{l}^{-1}$ concentrations caused $10 \%$ and $50 \%$ mortalities respectively alongwith slow growth and delayed metamorphosis as compared to $0.1 \mathrm{mg} \mathrm{l}^{-1}$ treatment and control (0 mg l-1). The non-specific immune parameters and certain enzyme activities like alkaline phosphatase (ALP), superoxide dismutase (SOD) and lactate dehydrogenase (LDH) varied significantly in a dose dependent manner. The accumulation of silver in the tadpole tissues of treated groups ranged from $0.0966 \pm 0.0025 \mu \mathrm{g} \mathrm{g}^{-1}$ to $0.4718 \pm 0.0126 \mu \mathrm{g} \mathrm{g}^{-1}$ as compared to tissues in control group $\left(0.0758 \pm 0.0019 \mu \mathrm{g} \mathrm{g}{ }^{-1}\right)$. Hence Ag-NPs had significant detrimental effects on growth and other associated physiological parameters of tadpole, Polypedates maculatus when administered at higher concentrations $\left(>1 \mathrm{mg} \mathrm{l}^{-1}\right)$ for longer durations. Thus the toxicity studies of Ag-NPs have to be conducted on wider ranges of target and non-target species to assess their environmental impacts. Furthermore, these results suggest that silver nanoparticles induce a dose-dependent toxicity in physiological parameters of tadpoles, which hinders normal development.This study was aimed to enhance our insight on the health and environmental impact of silver nanoparticles. This study pointed out the adverse effects of Ag-NPs in tadpole species and all applications involving silver nanoparticles should be given special attention and promoted only after detailed studies.
\end{abstract}

Keywords: Ag-NPs, growth, metamorphosis, immunity, enzyme profile, Polypedates maculatus

\section{Introduction}

Nanotechnology is a promising technology with extensive applications in human life. Its wide production and applications create major concerns for its possible danger to the environment. Aquatic ecosystems are one of the final destinations of released nanomaterials. These materials may have significant toxic harmful effects on the aquatic organisms including aquatic bacteria, unicellular and multicellular algae, zooplanktons, mollusca, crustaceans, amphibians and fishes. Despite various published research on nanoparticle toxicity in aquatic animals (Franklin et al., 2007; Zhu et al., 2008; Lovern and Klaper, 2006), the field on nano toxicology is relatively new. Furthermore, metal nanoparticles are the most widely produced nanoparticles with many applications (Kumar and Yadav, 2009). Among them silver nanoparticles, (Ag-NPs) are the most widely used nanoparticles in consumer products (Woodrow Wilson Database, 2011). Many studies have investigated the toxicity of Ag-NPs in both fishes and various mammalian models (Swain et al., 2014; Farman et al., 2012; Scown et al., 2010). Nevertheless, most of the investigations on toxicity of nanoparticles on aquatic vertebrates were focused on fishes (Bar-llan et al., 2012). Among various aquatic organisms, amphibians are excellent models for aquatic nanotoxicology studies since they have the potential of behaving as bioindicators and accumulating toxic substances. In addition to these, less attention has been paid on them regarding ecotoxicology compared to other vertebrates (Mouchet et al., 2008; Nations et al., 2011; Bacchetta et al., 2012; Zhang et al., 2012). Relatively few studies on effects of carbon nanotubes, cerium oxide $\left(\mathrm{CeO}_{2}\right)$ nanoparticles (Bour et al., 2015), silver (Ag) nanoparticles copper (II) oxide (CuO) nanoparticles, titanium dioxide $\left(\mathrm{TiO}_{2}\right)$ nanoparticles and zinc oxide ( $\mathrm{ZnO})$ nanoparticles (Bachetta et al., 2012; Birhanli et al., 2014; Nations et al., 2011; Zhang et al., 2012) on amphibians have been published; which have primarily 
utilized tadpoles of the African clawed frog (Xenopus laevis) as model organisms. In this study, the tadpoles of the tree frog, Polypedates maculatus (Gray, 1830) were selected to evaluate the toxicity of Ag-NPs. This species is one of the diverse and widely distributed frogs around world. It is easily available and has a significant role in ecological food chain. The present study investigates on how the exposure of tadpole larvae of Indian tree frog, P. maculatus to Ag-NPs affects their growth, metamorphosis, innate immunity and oxidative stress levels.

\section{Materials and Methods}

Fresh foam nests containing eggs of $P$. maculatus were collected from natural ponds in nearby areas with latitude $20^{\circ} 11^{\prime} 13.59^{\prime \prime} \mathrm{N}$ and longitude $85^{\circ} 51^{\prime} 12.798^{\prime \prime} \mathrm{E}$ during the month of September, 2017.Short and wide plastic tubs were used to house the tadpoles. Ag-NPs were purchased from Sisco Research Laboratory Pvt. Ltd. (SRL), Mumbai (Batch No. T-8361389; APS: <90 nm; Ag A.W. 107.87). The Ag-NPs initial stock suspension (1500 $\mathrm{mg} \mathrm{l}^{-1}$ ) was diluted (1:100) in Milli-Q water to make a working suspension of $15 \mathrm{mg} \mathrm{l}^{-1}$ (Das et al., 2013). It was observed that the $\mathrm{Ag}$ content of the AgNPs suspension was found to be $48.11 \mathrm{~nm}$ (Figure 1) based on Dynamic light Scattering (DLS), which was lower than the manufacturers claim. The tadpoles of Gosner stage-23 were collected. Plastic pots of typical size $\left(12^{\prime \prime} \times 10^{\prime \prime}\right)$ were taken for the experiment. Three treatments were designed with Ag-NPs @0.1 $\mathrm{mg} \mathrm{l}^{-1}\left(\mathrm{~T}_{1}\right), 1 \mathrm{mg} \mathrm{l}^{-1}\left(\mathrm{~T}_{2}\right), 5 \mathrm{mg} \mathrm{l}^{-1}\left(\mathrm{~T}_{3}\right)$ and control (C; $0 \mathrm{mg} \mathrm{l}^{-1}$ ). Twenty (20) tadpoles were taken in duplicates in each set for experimentation till 60 days.

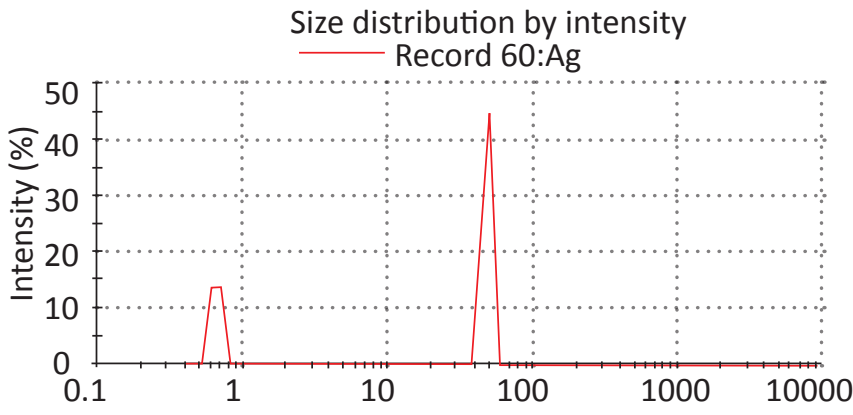

Figure 1: Dynamic light Scattering (DLS) of Ag-NPs suspension (Peak at: $48.11 \mathrm{~nm}$ )

Dechlorinated water was used throughout the experimental period. Tadpoles were fed with boiled Amaranthus leaves every alternate day. Once tadpoles were seen approaching frog let stage, tubs were covered with nets for rearing of the metamorphosed tadpoles. Experiments were conducted under 12L:12D photoperiod. Body length and weight measurements were taken at an interval of every 15 days using Vernier calipers and weighing machine. The behavior and mortality of the tadpoles were observed and recorded every day. Mortality was determined by lack of movement or response from external stimuli. The tadpoles sampled for analysis were placed on a Kimwipe tissue to remove any residual water from the aquarium, and then each tadpole was weighed and rapidly homogenized in liquid nitrogen with a mortar and pestle. The homogenized samples were added to equal volume of phosphate buffer saline $(\mathrm{pH} 7.2)$ with respect to body weight and centrifuged at $15,000 \mathrm{~g}$ for 30 minutes at $4{ }^{\circ} \mathrm{C}$. The supernatants from each tadpole group were collected using a micropipette and stored at -20 ${ }^{\circ} \mathrm{C}$. The supernatant was used to determine the immune and enzymatic parameters.

Myeloperoxidase activity was determinedaccording to Quadeand Roth (1997), $15 \mu \mathrm{l}$ of tadpole extract was diluted in $135 \mu \mathrm{l}$ of Hank's balanced salt solution ( $\mathrm{Ca}^{2+}, \mathrm{Mg}^{2+}$ free). $50 \mu \mathrm{l}$ of $20 \mathrm{mM}$ of 3, 3', 5, 5'-tetra methyl benzidine and 5 $\mathrm{mM}$ of hydrogen peroxide were added to it. The mixture was incubated for 2 minutes at room temperature. After incubation, the reaction was stopped by adding $4 \mathrm{M}$ sulphuric acid. The optical density of the samples was measured at $450 \mathrm{~nm}$ using the UV- VIS Spectrophotometer, Thermo Spectronic, UK.

The reduction of nitro blue tetrazolium (NBT) by intracellular superoxide radicals (Respiratory Burst Activity) was analyzed according to (Anderson and Siwicki, 1994). In brief, $50 \mu \mathrm{l}$ of PBS extract of each experimental group of tadpoles was mixed with $50 \mu \mathrm{l}$ of $0.2 \%$ NBT (Sigma, USA) solution. The mixture was incubated for 30 minutes at $25^{\circ} \mathrm{C}$. Now, $50 \mu$ of the above mixture was added to $1 \mathrm{ml}$ of $\mathrm{N}$,Ndiethyl methyl formamide (Qualigens, India). The entire mixture was then subjected to centrifugation at $6000 \mathrm{~g}$ for 5 minutes. The supernatant was collected, whose optical density was read at $540 \mathrm{~nm}$ using the UV-VIS Spectrophotometer, (Thermo Spectronic, UK).

The hemagglutination activity of the tadpole extracts was carried out as per the standardized method, described by (Blazer and Wolke, 1984). The assay was done in ' $U$ '- shaped microtiter plates. Two-fold serial dilution of tadpole extracts, $25 \mu \mathrm{l}$ each, was carried out using equal volume of NSS. $25 \mu \mathrm{l}$ of freshly prepared $1 \%$ New Zealand white rabbit red blood cell $(R B C)$ suspension was added to the wells. The plates were incubated at room temperature $\left(28-30^{\circ} \mathrm{C}\right)$ for 2 hours or at 4

${ }^{\circ} \mathrm{C}$ overnight, in case agglutination was not observed within 2 hours. The titer was calculated as the reciprocal of the highest dilution of serum showing complete agglutination of RBC. The hemolytic assay of tadpole extracts was carried out in a manner similar to one as described for HA titer (Blazer and Wolke, 1984). However in this case, the plates were incubated at room temperature overnight.

The bacterial agglutination activity test was carried out using ' $U$ ' shaped microtiter plates. Tadpole extracts, 25 $\mu l$ each were subjected to two fold serial dilution with an equal volume of NSS in each well. $25 \mu$ of formalin-killed A. hydrophila $\left(10^{7}\right.$ cells $\left.\mathrm{ml}^{-1}\right)$ suspension was added to each of the wells. Next, the plates were incubated overnight at $37^{\circ} \mathrm{C}$. The titer was calculated as the reciprocal of the highest dilution of serum showing complete agglutination of the bacterial cells. 
A lysozyme assay utilizing lyophilized Micrococcus lysodeikticus (Sigma, USA) was carried out as per the protocol, described by (Ellis, 1990). A volume of $130 \mu \mathrm{l}$ of freshly prepared $M$. Iysodeikticus solution at a concentration of $0.6 \mathrm{mg} \mathrm{ml}^{-1}$ (in $0.02 \mathrm{M}$ sodium citrate buffer) was added to a mixture containing $10 \mu \mathrm{l}$ tadpole extract and $10 \mu \mathrm{l}$ of 0.02 $M$ sodium citrate buffer. The initial Optical Density (OD) was measured at $450 \mathrm{~nm}$ as soon as the bacterial solution was added. The final OD of the samples was again measured at $450 \mathrm{~nm}$, following the incubation of samples for 1 hour at 24 ${ }^{\circ} \mathrm{C}$. Next, a standard curve was plotted using a mixture of 20 $\mu \mathrm{l}$ working standard and $130 \mu \mathrm{l}$ of $M$. lysodeikticus solution. Lysozyme activity was expressed in unit $\mathrm{ml}^{-1}$ where one unit is defined as the decrease in absorbance of $0.001 \mathrm{~min}^{-1}$.

The lactate dehydrogenase (LDH) activity in the tadpole extracts was assessed using the lactate dehydrogenase activity assay kit (Sigma- Aldrich Chemie, USA) following the manufacturer's instructions.

The alkaline phosphatase activity (ALP) in the tadpole extracts was determined using the Alkaline Phosphatase activity kit (Bio Vision, USA), following the manufacturer's instructions.

The super oxide dismutase (SOD) activity in the tadpole extracts was carried out using the SOD assay kit (SigmaAldrich Chemie, USA).

After 60 days, tadpoles from control and treated groups were analyzed for Ag accumulation in their tissues by ICP-MS (7500 cx, Agilent, USA). In brief, tadpoles were cleaned using running tap water followed by deionized water (Milli-Q, Millipore, USA) and kept at $-20^{\circ} \mathrm{C}$ for 5-10 minutes for inducing cold sleep to euthanize (Shine et al., 2015). Gut of the tadpoles was cleaned using sterilized razor and forceps. The tadpoles were patted dry using tissue paper and then homogenized. Wet samples were directly digested without drying, assuming the water content to be $78-80 \%$ (Anonymous, 2005). Finally, $1 \mathrm{~g}$ of the homogenized sample was treated with $5 \mathrm{ml}$ of concentrated nitric acid $\left(69 \% \mathrm{HNO}_{3}\right)$ and kept overnight. The sample was heated to $90-110^{\circ} \mathrm{C}$ on a hot plate till it was 1-0.5 $\mathrm{ml}$, and was allowed to cool. $1 \mathrm{ml}$ of $30 \%$ hydrogen peroxide was added to the cooled digest and digested further on the hot plate till the sample became colourless and reduced in volume up to around $0.5 \mathrm{ml}$. The digested sample was cooled, added to $1 \mathrm{ml}$ of deionized water and allowed to stand for 1 hour. After digestion, the sample was washed down three times using $1 \mathrm{ml}$ deionized water and filtered using (Whatman No.40) filter paper. The filtrate was finally diluted to $10 \mathrm{ml}$ using deionized water and was analyzed by ICP-MS.

\section{Results and Discussion}

The Ag content in tadpoles was found to be in an increasing order in different treated groups as compared to control (Table 1). The accumulation of measured Ag in the tissues was in the range of $0.0966 \pm 0.0025{\mu g^{-1}}^{-1}$ to $0.4718 \pm 0.0126 \mu \mathrm{g} \mathrm{g}^{-1}$

\begin{tabular}{|c|c|}
\hline Treatments & Level of accumulation in $\mu \mathrm{g} \mathrm{g}^{-1}$ (Mean $\pm \mathrm{SE}$ ) \\
\hline Control (C) & $0.0758 \pm 0.0019$ \\
\hline $\mathrm{T}_{1}$ & $0.0966 \pm 0.0025$ \\
\hline $\mathrm{T}_{2}$ & $0.2189 \pm 0.0066^{*}$ \\
\hline $\mathrm{T}_{3}$ & $0.4718 \pm 0.0126^{*}$ \\
\hline
\end{tabular}

( ${ }^{*}$ denotes significant $p<0.05$ )

in treated groups as compared to control $(0.0758 \pm 0.0019 \mu \mathrm{g}$ $\left.\mathrm{g}^{-1}\right)$ after 60 days of exposure. These results infer that tadpoles exposed to Ag-NPs for over 60 days accumulated more $\mathrm{Ag}$ in a dose-dependent manner. $\mathrm{Ag}$ can be oxidized to ionic $\mathrm{Ag}$ (Liu and Hurt, 2010), which then forms Ag complexes or precipitates. It is also possible for Ag-NPs to agglomerate into larger, less stable particles, leading to sedimentation. Loss in Ag-NPs can also be explained by their adsorption into various components of the systems to which they are exposed such as the walls of the container, the mucus on tadpole epithelium that eventually sloughs off and sediments, (Handy et al., 2012) other organic molecules like food proteins (Fabrega et al., 2011) which may be taken up by the tadpoles or may settle down at the tank bottom. These phenomena are likely to occur in the natural environment as well. Bioaccumulation occurs when a substance is absorbed by an organism at a greater rate than the rate at which it is lost. While Ag-NPs associated with food and present in the intestinal tracts of the tadpoles undoubtedly contributed to the observed Ag tissue concentrations, it is difficult to completely account for all measured Ag. Several routes exist for Ag-NPs internalization, including uptake by contact with the gill and skin epithelia. A number of studies have demonstrated increase in total Ag content associated with fish gills after Ag-NPs exposure (Scown et al., 2010; Farmen et al., 2012). Moreover, unlike fishes, which have a protective layer of scales, the uptake of Ag-NPs directly through the epidermis is possible in amphibians due to their semipermeable skin. Ag-NPs can accumulate in biofilms which tadpoles may ingest. Since up to $40 \%$ of dissolved $\mathrm{Ag}$ was present in the exposed water of the current experiment, it is unclear whether the measured $\mathrm{Ag}$ in tissues was internalized in its particulate form or got dissolved. Ionic Ag, liberated, can also be directly taken up into tissues via membrane ion transporters, similar to uptake of $\mathrm{Na}^{+}$and $\mathrm{Cu}^{2+}$ ions (Fabrega et al., 2011). After the release of ionic $\mathrm{Ag}$ into the environment, concentrations above $2 \mathrm{~g} \mathrm{Ag} \mathrm{g}^{-1}$ tissue caused sterility in clams (Brown et al., 2003). It would therefore be of interest to investigate further the effects of AgNPs in other amphibians with different doses and durations. According to (Carew et al., 2015), tadpoles (Xenopus laevis) bioaccumulated Ag-NPs and displayed transient alterations in snout, vent hind limb length and overall body weight when exposed to them for longer durations. 
The growth, metamorphosis and survivability were found affected due to exposure to Ag-NPs. Chronic exposure to $\mathrm{Ag}$-NPs did not alter the rate of metamorphosis at any dose in any of the treated groups. In control groups, lengths of tadpoles remained unaltered whereas in treated groups, body lengths decreased after 15 days of exposure (Table 2-4). The

Table 2: Effects of Ag-NPs $\left(0.1 \mathrm{mg} \mathrm{l}^{-1}\right)$ on growth and survivability of control and Treated tadpoles of Polypedates maculatus

\begin{tabular}{|c|c|c|c|c|c|c|c|}
\hline \multirow{2}{*}{$\begin{array}{l}\text { SI. } \\
\text { No. }\end{array}$} & \multicolumn{4}{|c|}{ Control } & \multicolumn{3}{|c|}{ Treated } \\
\hline & Days & $\begin{array}{l}\text { Average body } \\
\text { length }(\mathrm{cm})\end{array}$ & $\begin{array}{c}\text { Average body } \\
\text { weight (g) }\end{array}$ & $\begin{array}{l}\text { Survivability } \\
\text { (\%) }\end{array}$ & $\begin{array}{l}\text { Average body } \\
\text { length }(\mathrm{cm})\end{array}$ & $\begin{array}{l}\text { Average body } \\
\text { weight (g) }\end{array}$ & Survivability (\%) \\
\hline 1. & Day 1 & 1.9 & 0.08 & 100 & 1.8 & 0.07 & 100 \\
\hline 2. & Day 15 & 2.8 & 0.1 & 100 & 2.6 & 0.09 & 100 \\
\hline 3. & Day 30 & 3.1 & 0.18 & 100 & 2.9 & 0.15 & 100 \\
\hline 4. & Day 45 & 3.2 & 0.25 & 100 & 3.1 & 0.18 & 100 \\
\hline 5. & Day 60 & 3.4 & 0.29 & 100 & 3.2 & 0.26 & 100 \\
\hline
\end{tabular}

Table 3: Effects of Ag-NPs $\left(1 \mathrm{mg}^{-1}\right)$ on growth and survivability of control and treated tadpoles of Polypedates maculatus

\begin{tabular}{|c|c|c|c|c|c|c|c|}
\hline \multirow{2}{*}{$\begin{array}{l}\text { SI. } \\
\text { No. }\end{array}$} & \multicolumn{4}{|c|}{ Control } & \multicolumn{3}{|c|}{ Treated } \\
\hline & Days & $\begin{array}{l}\text { Average body } \\
\text { length }(\mathrm{cm})\end{array}$ & $\begin{array}{c}\text { Average body } \\
\text { weight (g) }\end{array}$ & $\begin{array}{c}\text { Survivability } \\
\text { (\%) }\end{array}$ & $\begin{array}{l}\text { Average body } \\
\text { length }(\mathrm{cm})\end{array}$ & $\begin{array}{l}\text { Average body } \\
\text { weight (g) }\end{array}$ & Survivability (\%) \\
\hline 1. & Day 1 & 1.7 & 0.068 & 100 & 1.8 & 0.067 & 100 \\
\hline 2. & Day 15 & 2.3 & 0.09 & 100 & 2.1 & 0.07 & 100 \\
\hline 3. & Day 30 & 2.8 & 0.19 & 100 & 2.4 & 0.14 & 100 \\
\hline 4. & Day 45 & 2.9 & 0.21 & 100 & 2.5 & 0.16 & 90 \\
\hline 5. & Day 60 & 3 & 0.23 & 100 & 2.6 & 0.19 & 90 \\
\hline
\end{tabular}

Table 4: Effects of Ag-NPs $\left(5 \mathrm{mg}^{\left.\right|^{-1}}\right)$ on growth and survivability of control and treated tadpoles of Polypedates maculatus

\begin{tabular}{|c|c|c|c|c|c|c|c|}
\hline \multirow{2}{*}{$\begin{array}{l}\text { SI. } \\
\text { No. }\end{array}$} & \multicolumn{4}{|c|}{ Control } & \multicolumn{3}{|c|}{ Treated } \\
\hline & Days & $\begin{array}{l}\text { Average body } \\
\text { length }(\mathrm{cm})\end{array}$ & $\begin{array}{l}\text { Average body } \\
\text { weight (g) }\end{array}$ & $\begin{array}{l}\text { Survivability } \\
\text { (\%) }\end{array}$ & $\begin{array}{l}\text { Average body } \\
\text { length }(\mathrm{cm})\end{array}$ & $\begin{array}{c}\text { Average body } \\
\text { weight (g) }\end{array}$ & Survivability (\%) \\
\hline 1. & Day 1 & 1.8 & 0.06 & 100 & 1.7 & 0.05 & 100 \\
\hline 2. & Day 15 & 2.9 & 0.09 & 100 & 2.7 & 0.09 & 100 \\
\hline 3. & Day 30 & 3.9 & 0.19 & 100 & 3.7 & 0.19 & 100 \\
\hline 4. & Day 45 & 4 & 0.20 & 100 & 3.8 & 0.19 & 80 \\
\hline 5. & Day 60 & 4.1 & 0.21 & 100 & 3.9 & 0.2 & 50 \\
\hline
\end{tabular}

effects of Ag-NPs on morphology were transient and subtle, especially when observed at higher doses for longer durations. This is not surprising since Ag-NPs are toxic to the larvae and damage tissues in fishes as well as in mammalian models (Hosseini et al., 2014). It was because of the temporal nature of the Ag-NPs that the morphology, developmental processes, metamorphosis in Xenopous laevis got affected at relatively lower concentrations (Carew et al., 2015).

Induction of innate immunity by metal nanoparticles is a hypothesis which may be proved in the near future. Though many studies have already proven it partially, our present study specifically presents evidence on consistent innate immune stimulating effects for the first time in amphibians like tadpoles. Selected innate parameters of the immune system have been examined, such as respiratory burst activity, myeloperoxidase, bacterial agglutination and lysozyme activities which were significantly higher in all the treated groups as compared to control ones, as depicted in Figure2-6. However, hemagglutination activities show no significant alternation in both control and treated groups. (Asharani et al., 2008) reported that silver nanoparticles reduced ATP content of the cell, caused damage to mitochondria and increased production of reactive oxygen species (ROS) in a dose-dependent manner which may also be one of the abnormality signs, found in our study. Very little is known about the ontogeny and the functioning of the immune system in tadpole larvae.

The enzyme parameters such as alkaline phosphatase (ALP), 
superoxide dismutase (SOD) and lactate dehydrogenase (LDH) activities were found to have increased in all Ag-NPs treated groups in a dose dependent manner as compared to control. The results have been shown in Figure 7-9. One of the main mechanisms of action of Ag-NPs is by causing oxidative stress and intracellular damage from ROS production (AshaRani et al., 2009; Marambio-Jones and Hoek, 2010; Yildirimer et al., 2011; Zhang et al., 2012). While their primary function is to cause breakdown of phagocytosed substances, they also play an important role as secondary regulators of ROS, after catalases, superoxide-dismutases and glutathione peroxidases

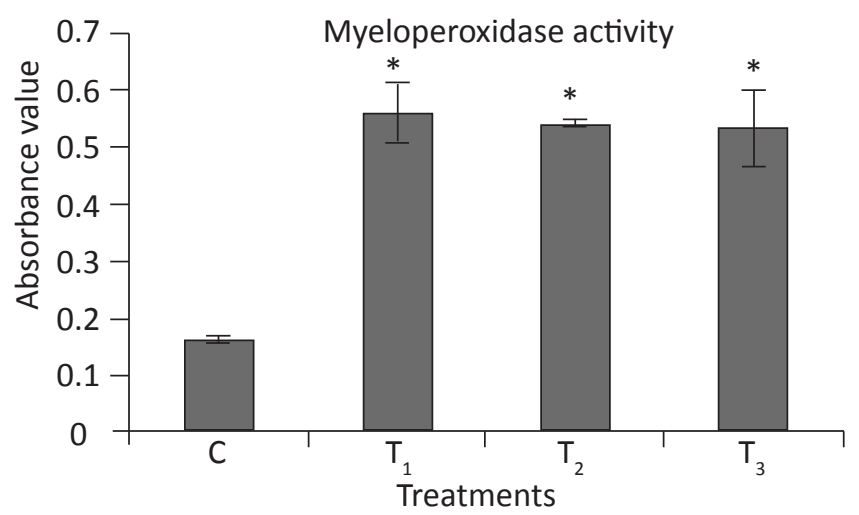

Figure 2: Effect of Ag-NPs on Myeloperoxidase activity of tadpoles. The values represent the mean $\pm S E$

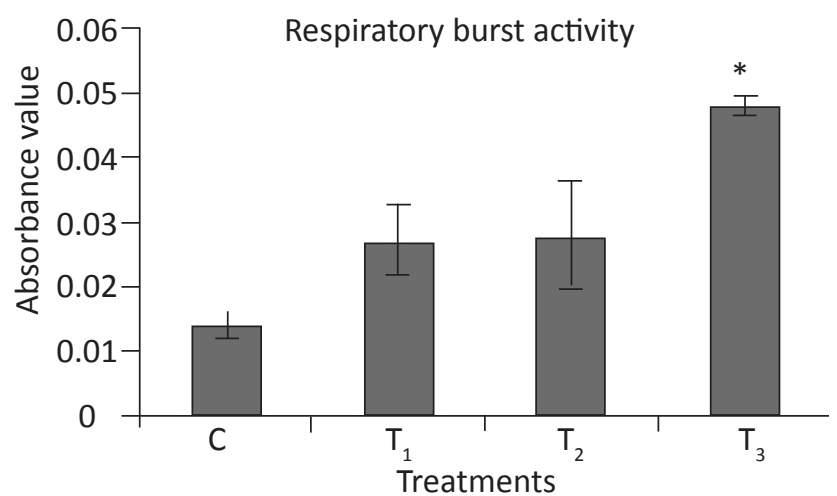

Figure 3: Effect of Ag-NPs on Respiratory burst activity of tadpoles. The values represent the mean $\pm S E$

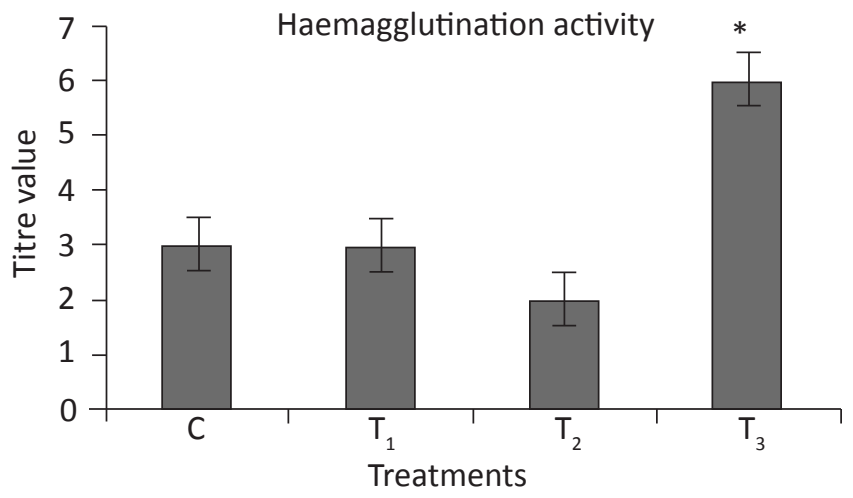

Figure 4: Effect of Ag-NPs Haemagglutination activity of tadpoles. The values represent the mean $\pm \mathrm{SE}$

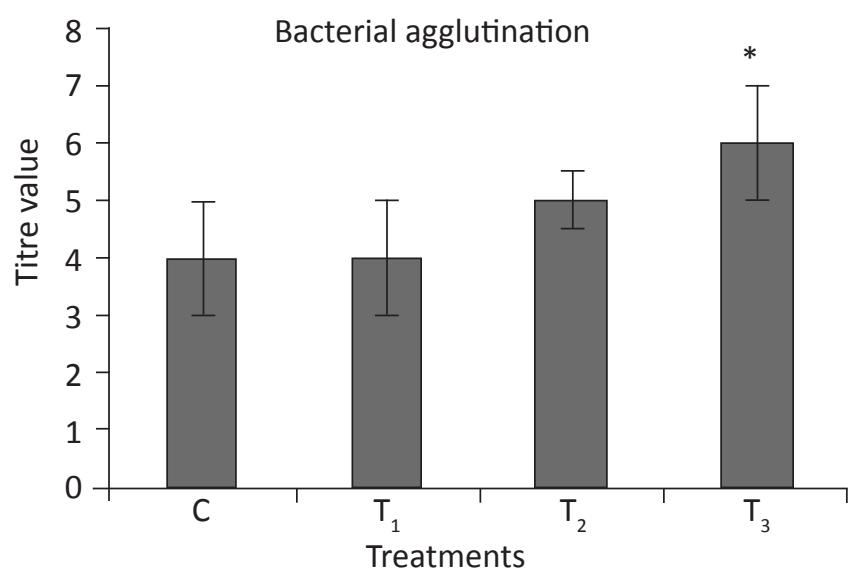

Figure 5: Effect of Ag-NPs Bacterial agglutination of tadpoles. The values represent the mean $\pm S E$

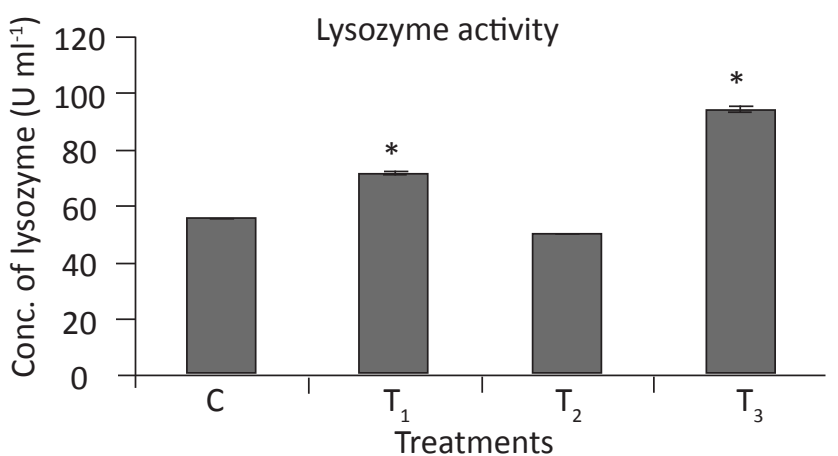

Figure 6: Effect of Ag-NPs on Lysozyme activity of tadpoles. The values represent the mean \pm SE

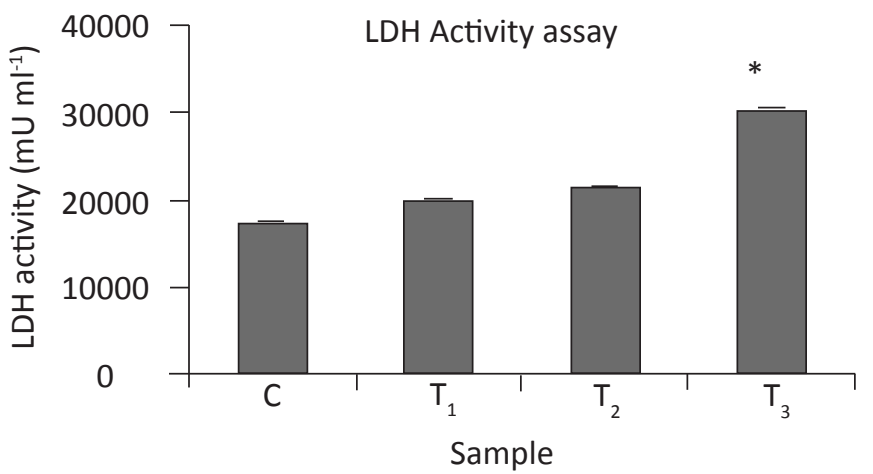

Figure 7: Effect of Ag-NPs on LDH activity of tadpoles. The values represent the mean $\pm S E$

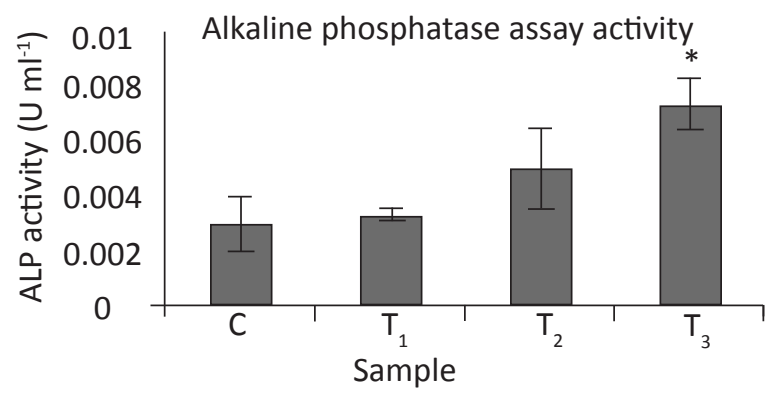

Figure 8: Effect of Ag-NPs on ALP activity of tadpoles. The values represent the mean $\pm \mathrm{SE}$ 


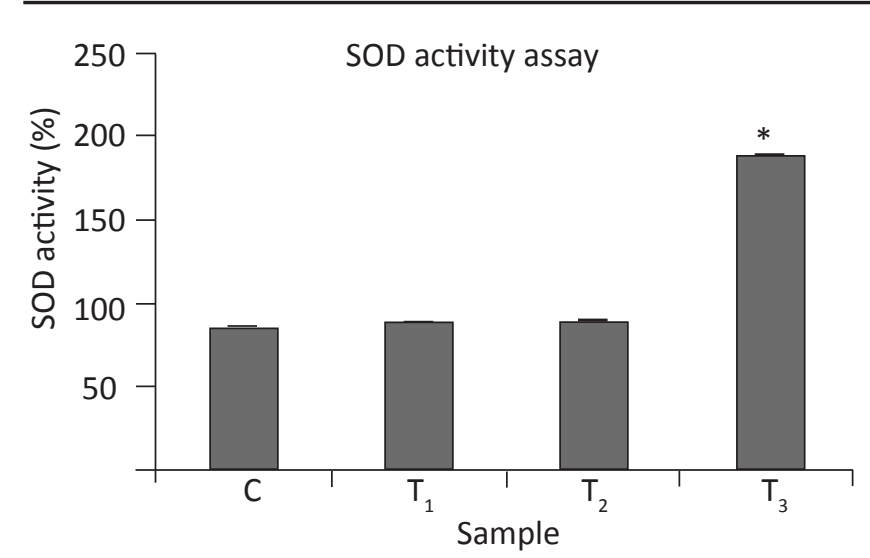

Figure 9: Effect of Ag-NPs on SOD activity of tadpoles. The values represent the mean $\pm \mathrm{SE}$

Figures (2-9): Effect of Ag-NPs on physiological parameters of tadpoles $\left(\mathrm{T}_{1}-\mathrm{T}_{3}\right)$. The values represent the mean $\pm \mathrm{SE}$. ( ${ }^{*}$ denotes significant value $(p<0.05)$.

in immune compromised states (Schaffer and Bronnikova, 2012). Studies show that the responses of many aquatic animals such as fishes to these targets cause Ag-NPs induced ROS generation, the deleterious effects of which, at various concentrations, are yet to be determined. The present study targeted its effects on tadpole larvae which are amphibians. Ag-NPs significantly increased alkaline phosphatase (ALP), superoxide dismutase (SOD) and lactate dehydrogenase (LDH) activities in all the treated groups as compared to control. Moreover, there was a significant difference in enzymatic profiles in tadpole groups, treated with the highest Ag-NPs concentration $\left(T_{3}\right)$ than in the other treated groups $\left(T_{1}\right.$ and $\mathrm{T}_{2}$ ). Some previous studies have reported that the toxicity of nanoparticles is dose dependent which means nanoparticles at higher doses are more toxic as compared to nanoparticles at lower doses (Buzea et al., 2007). It may be related to the fact that nanoparticles having smaller sizes, when supplied at higher doses, pass through biological barriers more easily, thereby causing toxicity and oxidative stress. Yet, further investigations are needed to confirm such response patterns. In contrast, tadpoles of $X$. laevis, when exposed to TiSiO4 NPs revealed a decrease in lactate and alanine contents (Carew et al., 2015). Several researchers have also shown that Ag-NPs cause severe oxidative stress and alternation in antioxidant activities in not only fishes but also tadpoles. Therefore, in the present study, it was confirmed from LDH and ALP enzyme profiles that tadpoles were under stress and tissue damage conditions. SOD activity is the most widely used measure of oxidative stress. The SOD activity of $P$. maculatus was found to have increased in treated groups. (Sedeno-Diazand et al., 2012) found that the SOD activity increased or diminished based on the concentration of metals. The tissue absorbance of Ag was highest recorded in $5 \mathrm{mg} \mathrm{l}^{-1}$ silver nanoparticle treatment. Least accumulation of Ag was found at lower concentrations as compared to the higher ones. This result inferred that at lower concentrations, heavy metal accumulation was less toxic and overall body growth and development of tadpoles was least affected as compared to their higher doses of treatment. Similar results were also reported in salmon fishes (Farmen et al., 2012). Furthermore, increase in alkaline phosphatase (ALP) levels damage the cells since these enzymes are located within the cells, thus enabling them to get incorporated into the serum from injured cells.

\section{Conclusion}

Ag-NPs has significant effects on growth and other associated physiological parameters like immunity and enzymatic profile of tadpole, Polypedates maculatus when administered at certain concentrations (>1 $\mathrm{mg} \mathrm{l}^{-1}$ ) for longer durations. Hence, the toxicity studies of synthesized Ag-NPs should be conducted on wider ranges of target and non-target species to assess their environmental impacts and sustainable management. The release of untreated nanoparticle waste to the environment should be restricted for the wellbeing of aquatic species.

\section{Acknowledgement}

All the authors are thankful to Indian Council of Agricultural Research (ICAR) for financial support throughout the research period under ICAR-National Fellow scheme: "Nanotechnology in aquaculture: an alternative approach for fish health management and water remediation "( $\mathrm{F}$. No. 27(3)/2010-HRD date 17 Feb, 2011). Authors are also grateful to Director, ICAR-Central Institute of Freshwater Aquaculture, Bhubaneswar; VC, Orissa University of Agriculture and Technology, Bhubaneswarand Director, CSIR-National Botanical Research Institute, Lucknow for providing all kinds of basic facilities to conduct the present investigation.

\section{References}

Anderson, D.P., Siwicki, A.K., 1994. Duration of protection against Aeromonas salmonicida in brook trout immunostimulated with glucan or chitosan by injection or immersion. The Progressive Fish-Culturist 56(4), 258-261.

Anonymous, 2005.Analysis of Major, Minor and Trace Elements in Animal Tissue Samples with ICP-OES and ICP-MS. Available at http://uwlab.soils.wisc.edu.

Asharani, P.V., Lian, W.Y., Gong, Z., Valiyaveettil, S., 2008. Toxicity of silver nanoparticles in zebrafish models. Nanotechnology 19, 255102. doi:10.1088/09574484/19/25/255102

AshaRani, P.V., Low, K.M.G., Hande, M.P., Valiyaveettil, S., 2009. Cytotoxicity and genotoxicity of silver nanoparticles in human cells. ACS Nano 3(2), 279-290.

Bacchetta, R., Santo, N., Fascio, U., Moschini, E., Freddi, S., Chirico, G., Camatini, M., Mantecca, P., 2012. Nano-sized $\mathrm{CuO}, \mathrm{TiO}_{2}$ and $\mathrm{ZnO}$ affect Xenopus laevis development. Nanotoxicology 6(4), 381-398.doi: 
10.3109/17435390.2011.579634

Bar-Ilan, O., Louis, K.M., Yang, S.P., Pedersen, J.A., Hamers, R.J., Peterson, R.E., Heideman, W., 2012. Titanium dioxide nanoparticles produce phototoxicity in the developing zebrafish. Nanotoxicology 6(6), 670-679. https://doi.org/10.3109/17435390.2011.604438.

Birhanli, A., Emre, F.B., Sayilkan, F., Gungordu, A., 2014. Effect of nanosized $\mathrm{TiO}_{2}$ particles on the development of Xenopuslaevis embryos. Turkish Journal of Biology 38(2), 283-288.doi:10.3906/biy-1307-1337.

Blazer, V.S., Wolke, R.E., 1984.The effects of $\alpha$-tocopherol on the immune response and non-specific resistance factors of rainbow trout (Salmogairdneri Richardson). Aquaculture 37(1), 1-9. https://doi.org/10.1016/00448486(84)90039-5.

Bour, A., Mouchet, F., Verneuil, L., Evariste, L., Silvestre, J., Pinelli, E., Gauthier, L., 2015. Toxicity of $\mathrm{CeO}_{2}$ nanoparticles at different trophic levels-effects on diatoms, chironomids and amphibians.Chemosphere 120, 230-6. doi: 10.1016/j.chemosphere.2014.07.012

Brown, C.L., Parchaso, F., Thompson, K.J., Luoma, S.N., 2003. Assessing Toxicant Effects in a Complex Estuary: A Case Study of Effects of Silver on Reproduction in the Bivalve, Potamocorbula amurensis, in San Francisco Bay. Human and Ecological Risk Assessment 9 (1), 95-119. https:// doi.org/10.1080/713609854.

Buzea, C., Pacheco, I.I., Robbie, K., 2007. Nanomaterials and nanoparticles: Sources and toxicity. Biointerphases 2(4), MR17-71. https://doi.org/10.1116/1.2815690

Carew, A.C., Hoque, M.E., Metcalfe, C.D., Peyrot, C., Wilkinson, K.J., Helbing, C.C., 2015. Chronic sublethal exposure to silver nanoparticles disrupts thyroid hormone signaling during Xenopuslaevis metamorphosis. Aquatic Toxicology 159, 99-108.doi: 10.1016/j. aquatox.2014.12.005.

Das, P., Xenopoulos, M.A., Metcalfe, C.D., 2013. Toxicity of silver and titanium dioxide nanoparticle suspensions to the aquatic invertebrate, Daphnia magna. Bulletin of Environmental Contamination \& Toxicology 91(1), 76-82. Doi: 10.1007/s00128-013-1015-6.

Ellis, A.E., 1990. Serum antiproteases in fish. Techniques in fish immunology 1, 95-99.

Fabrega, J., Luoma, S.N., Tyler, C.R., Galloway, T.S., Lead, J.R., 2011. Silver nanoparticles: behaviour and effects in the aquatic environment. Environment International 37(2), 517-531.doi: 10.1016/j.envint.2010.10.012

Farmen, E., Mikkelsen, H.N., Evensen, $\varnothing$., Einset, J., Heier, L.S., Rosseland, B.O., Salbu, B., Tollefsen, K.E., Oughton, D.H., 2012. Acute and sub-lethal effects in juvenile Atlantic salmon exposed to low $\mu \mathrm{g}^{-1}$ concentrations of Ag nanoparticles. Aquatic Toxicology 108, 78-84. Doi: 10.1016/j.aquatox.2011.07.007.

Franklin, N.M., Rogers, N.J., Apte, S.C., Batley, G.E., Gadd, G.E., Casey, P.S., 2007. Comparative toxicity of nanoparticulate $\mathrm{ZnO}$, bulk $\mathrm{ZnO}$, and $\mathrm{ZnCl}_{2}$ to a freshwater microalga (Pseudokirchneriella subcapitata): the importance of particle solubility. Environmental Science \& Technology 41(24), 8484-8490. DOI: 10.1021/ es071445r.

Gray, J.E., 1830. Description of Polypedates maculatus. Illustrations of Indian Zoology, 83.

Handy, R.D., Cornelis, G., Fernandes, T., Tsyusko, O., Decho, A., Sabo-Attwood, T., Metcalfe, C., Steevens, J.A., Klaine, S.J., Koelmans, A.A., Horne, N., 2012.Ecotoxicity test methods for engineered nanomaterials: practical experiences and recommendations from the bench. Environmental Toxicology and Chemistry 31, 15-31. doi: 10.1002/etc.706.

Hosseini, S.J., Habibi, L., Johari, S.A., Sourinejad, I., 2014. Acute toxicity of synthetic colloidal silver nanoparticles produced by laser ablation method to Eastern mosquito fish, Gambusiaholbrooki. Journal of Aquatic Ecology 4 (2), 30-34. http://jae.hormozgan.ac.ir/article-1-25-en. html.

Kumar, V., Yadav, S.K., 2009.Plant-mediated synthesis of silver and gold nanoparticles and their applications. Journal of Chemical Technology \& Biotechnology 84, 151-157. https://doi.org/10.1002/jctb.2023

Liu, J., Hurt, R.H., 2010. Ion release kinetics and particle persistence in aqueous nano-silver colloids. Environmental Science and Technology 44(6), 2169-75. DOI: 10.1021/es9035557.

Lovern, S.B., Klaper, R., 2006. Daphnia magna mortality when exposed to titanium dioxide and fullerene (C60) nanoparticles. Environmental Toxicology and Chemistry 25(4), 1132-1137.

Marambio-Jones, C., Hoek, E.M., 2010.A review of the antibacterial effects of silver nanomaterials and potential implications for human health and the environment. Journal of Nanoparticle Research 12(5), 1531-51.10.1007/s11051-010-9900-y.

Mouchet, F., Landois, P., Sarremejean, E., Bernard, G., Puech, P., Pinelli, E., Flahaut, E., Gauthier, L., 2008. Characterization and in vivo ecotoxicity evaluation of double-wall carbon nanotubes in larvae of the amphibian Xenopuslaevis.Aquatic Toxicology 87(2), 127-37. doi: 10.1016/j.aquatox.2008.01.011

Nations, S., Wages, M., Canas, J.E., Maul, J., Theodorakis, C., Cobb, G.P., 2011. Acute effects of $\mathrm{Fe}_{2} \mathrm{O}_{3}, \mathrm{TiO}_{2}, \mathrm{ZnO}$ and CuOnanomaterials on Xenopuslaevis. Chemosphere 83(8), 1053-61.doi: 10.1016/j.chemosphere.2011.01.061

Quade, M.J., Roth, J.A., 1997. A rapid, direct assay to measure degranulation of bovine neutrophil primary granules. Veterinary Immunology and Immunopathology 58(3), 239-48.

Schaffer, W.M., Bronnikova, T.V., 2012. Peroxidase-ROS interactions. Nonlinear Dynamics 68(3), 413-30.

Scown, T.M., Van, A.R., Tyler, C.R., 2010. Do engineered 
nanoparticles pose a significant threat to the aquatic environment? Critical Reviews in Toxicology 40(7), 653-670.

Shine, R., Amiel, J., Munn, A.J., Stewart, M., Vyssotski, A.L., Lesku, J.A., 2015. Is "cooling then freezing" a humane way to kill amphibians and reptiles? Biology Open 4, 760-763 doi:10.1242/bio.012179.

Swain, P., Nayak, S.K., Sasmal, A., Behera, T., Barik, S.K., Swain, S.K., Mishra, S.S., Sen, A.K., Das, J.K., Jayasankar, P., 2014. Antimicrobial activity of metal based nanoparticles against microbes associated with diseases in aquaculture. World Journal of Microbiology and Biotechnology 30(9), 2491-502.doi: 10.1007/s11274-014-1674-4.

Woodrow Wilson Database, 2011. Nanotechnology consumer product inventory. Available from http://www. nanotechproject.org/inventories/consumer/analysis_ draft/.

Yildirimer, L., Thanh, N.T., Loizidou, M., Seifalian, A.M., 2011. Toxicology and clinical potential of nanoparticles. Nano today 6(6), 585-607.
Zhang, J., Wages, M., Cox, S.B., Maul, J.D., Li, Y., Barnes, M., Hope-Weeks, L., Cobb, G.P., 2012. Effect of titanium dioxide nanomaterials and ultraviolet light co exposure on African clawed frogs (Xenopuslaevis). Environmental Toxicology and Chemistry 31(1), 176-183. doi: 10.1002/ etc.718.

Zhu, X., Zhu, L., Duan, Z., Qi, R., Li, Y., Lang, Y., 2008. Comparative toxicity of several metal oxide nanoparticle aqueous suspensions to Zebrafish (Daniorerio) early developmental stage. Journal of environmental science and health. Part A, Toxic/hazardous substances \& environmental engineering. 43 (3), 278-84.doi: 10.1080/10934520701792779.

Jacinto ElíasSedeno-Diaz and Eugenia Lopez-Lopez.2013. Freshwater Fish as Sentinel Organisms: From the Molecular to the Population Level, a Review in New Advances and Contributions to Fish Biology; http:// dx.doi.org/10.5772/54825. 